Military Technical College

Kobry El-Kobbah,

Cairo, Egypt

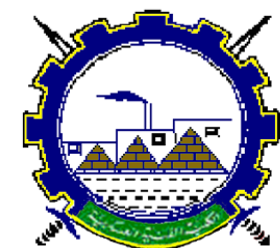

I.C.E.E.2016 $8^{\text {th }}$ International Conference

on

Chemical \& Environmental

Engineering

19 - 21 April 2016

\title{
EM-3
}

\section{Hybrid Rocket Motor: Propellant Selection and Fuel Grain Design}

\begin{abstract}
Ah. EL-S. MAKLED*
Abstract:

Hybrid rocket motor propellant offers a number of advantages over the traditional liquid and solid propellants, particularly in the areas of safety, cost and environmental effects. The combustion mechanism and internal ballistics of hybrid rocket motor (HRM) differs markedly from those in liquid engine and solid motor. Prediction of internal ballistic parameters of HRM is greatly affected by the instantaneous port geometry of the solid fuel grain during firing and types of oxidizer and fuel.

This paper discusses the design and selection criteria of HRM propellant (solid fuel, gas or liquid oxidizer and energetic additives), fuel grain geometry and operating parameters. The three basic elementary geometries namely, tube, pie-shaped, and triangular ports are used to describe more complicated hybrid grain configurations. Consequently burning perimeter, effective port area, fuel grain cross section area, filling coefficient (greater than $50 \%$ ) and sliver ratio (about 6\%) can be calculated.

Comprehensive static tests for small scale hybrid rocket motor have been carried out for various solid fuel materials (PMMA, PE, PE+AL, paraffin, bees wax) with gas oxygen as oxidizer. Finally, the designer selects a propellant type that is likely to give the required performance, considering cost, mechanical properties as well as the necessary storage stability and the best safety properties (non-toxic and smokeless).
\end{abstract}

Keywords: hybrid rocket motor, hybrid propellant, solid fuel grain, oxidizer.

\footnotetext{
* Egyptian Armed Forces
} 
Military Technical College

Kobry El-Kobbah,

Cairo, Egypt

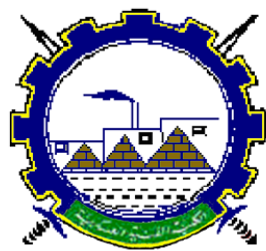

I.C.E.E.2016 $8^{\text {th }}$ International Conference

on

Chemical \& Environmental

Engineering

$19-21$ April 2016

\section{1: Introduction}

In a HRM a liquid or gas oxidizer is sprayed into the combustion chamber which contains a solid fuel active channel port. Hybrid propellant propulsion can give higher specific impulse than solid propellant propulsion; it has on-off and throttled operation, more safe in storage and handling, more reliable and simpler hardware than liquid propellant propulsion.

To exploit fully the advantages of hybrid rockets it is necessary to achieve a high performance concerning thrust and regression rate and minimum shift of operating parameters. The designer mainly has a tendency to satisfy minimum shift of operating parameters (mixture ratio, chamber pressure, regression rate and thrust during firing), moreover to satisfy maximum regression rate and specific impulse.

The primary characteristic of a HRM propellant that separates physically storage of solid fuel and oxidizer items, renders no potential for self-ignition, capability of explosion or detonation of the propellants.

The HRM propellant as solid fuel and gas or liquid oxidizer is the wide choice of solid and liquid propellants available to the propulsion system designer. The oxidizer can be one of a variety of liquid or gaseous oxidizers, which have been used with liquid engines and the list of possible solid fuels is virtually endless, each of these materials has chain terminators, such as the hydroxyl or carboxyl ion.

The proper solid fuel grain design must give the required port diameter for mixture ratio program, which is essential for hybrid engine design. In certain applications, the design must have a high propellant mass fraction with small final losses and constant operating internal ballistic parameters with high performance.

In the majority of cases, the grain length is required to be short with the highest possible regression rate and the minimum mixture ratio shift during operation. This requirement is not generally valid. Consequently, there exist special geometrical shapes of fuel grain charges. Typical shapes are shown in Fig. (1).

The relatively low regression rates of solid fuels (PE, PMMA, HTPB) have been among the major drawbacks of classical hybrid propellant technology due to heat transfer controlled combustion process. The thermal degradation process of inert polymeric fuels has been considered one of the key processes occurring in hybrid propellant [1,2]. The solid fuelsurface regression rate generated by this process is a very important design and performance parameter. The regression rate is strongly affected by the operating conditions, the composition and the thermo-physical properties of the solid fuel. In addition, fluid dynamic, heat-transfer, and combustion processes in these solid-fuel systems are characterized by complex interactions involving numerous simultaneous physical phenomena. These complex interactions include: solid-fuel polarizes, metal vaporization for solid fuels, oxidizer atomization and vaporization, gas-phase species mass diffusion, mixing and combustion of the fuel and oxidizer species; turbulent flow with mass addition, conductive, convective, and radiative heat transfer, and fuel grain varying flow-channel configuration with operating time. 
Military Technical College

Kobry El-Kobbah,

Cairo, Egypt

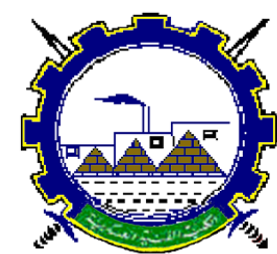

I.C.E.E.2016 $8^{\text {th }}$ International Conference

on

Chemical \& Environmental

Engineering

$19-21$ April 2016

Until now, regression rates of conventional solid fuels have typically been an order of magnitude lower than approximately $1 / 3$ time of that of solid propellants. Hence, a relatively large fuel-surface area is required to produce a desired thrust level.

Hybrid propellant propulsion, technical challenges are:

- Low regression rates for classical hybrid fuels,

- Combustion instabilities,

- Low combustion efficiency,

- Change of operating parameters during firing time,

Solutions to these technical issues should be such that they do not compromise the simplicity, safety and cost.

Generally, performance enhancement techniques of solid fuel material can be broken down to:

- Adding energetic materials into the solid-fuel grain,

- Using solid fuel based on high molecular weight as Beeswax, Lard and Paraffin,

- Using post-combustion chamber or mixing diaphragm.

\section{Geometric Analysis of the Fuel Grain}

Special fuel grain geometries are used with HRM, as shown in Fig. (1), they include multicylindrical, double-D active channel, wagon wheel triangle and special geometry active channel.

The proper fuel grain design must give the required mass flow rate of combustion gases to create the required combustion chamber pressure $P_{c}$ and thrust-time programs. The design must have a high propellant filling coefficient $\eta_{\mathrm{vg}}$ (greater than $50 \%$ ) and small final losses $\eta_{\text {sliver }}($ less than $6 \%$ ). In majority of applications, the grain length is required to be as short as possible, and the performance parameters (mixture ratio, combustion pressure and regression rate) shift to be minimum during the whole time of combustion.

The fuel grain geometries theoretical analysis deals with the following three independent geometric parameters: grain outer radius $\mathrm{R}_{0}$, number of port areas $\mathrm{N}$, and web thickness $\mathrm{w}$. Fig. (2) shows the three basic elementary geometries namely, tube, pie-shaped, and triangular ports, which are used to describe the more complicates hybrid grain configurations Fig. (1). The fuel grain geometry parameters to be calculated involve, burning perimeter $\mathrm{P}_{\mathrm{er}}$, effective port area $A_{\text {po }}$, fuel grain cross section area $A_{\text {fu }}$, filling coefficient $\eta_{\mathrm{vg}}$, and sliver amount $\eta_{\text {sliver }}$.

\section{2-1. Basic Elementary Geometries}

Consider a grain is known with three independent geometric parameters $\left(\mathrm{R}_{0}, \mathrm{~N}\right.$ and $\left.\mathrm{w}\right)$. To predict ballistic behavior, the regression rate equations have to be used to deduce the instantaneous geometrical parameters of the fuel grain. The $\mathrm{P}_{\mathrm{er}}, \mathrm{A}_{\mathrm{po}}$ and $\mathrm{A}_{\mathrm{fu}}$ could be given as function of the burnt distance $y$, or, in terms of burning time $t_{y}$ as the following: 
Military Technical College

Kobry El-Kobbah,

Cairo, Egypt

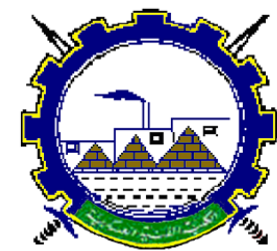

I.C.E.E. 2016 $8^{\text {th }}$ International Conference

on

Chemical \& Environmental

Engineering

19-21 April 2016

a- Circular Geometry, Fig. 2(a)

$$
\begin{aligned}
& P_{e r}(t)=2 N \pi\left(R_{o}-w+y\right)=2 N \pi\left(R_{o}-w+\int_{0}^{t_{y}} \dot{r}_{f u} d t\right) \\
& A_{p o}(t)=A_{p o, i}+\Delta A_{p o}(y)=N \pi\left(R_{o}-w\right)^{2}+N \pi\left[\left(R_{o}-w++\int_{0}^{t_{v}} \dot{r}_{f u} d t-\delta^{*}\right)^{2}-\left(R_{o}-w-\delta^{*}\right)^{2}\right] \\
& A_{f u}(t)=N \pi\left[R_{o}^{2}-\left(R_{o}-w+\int_{0}^{t_{v}} \dot{r}_{f u} d t\right)^{2}\right] \\
& A_{f u, i}=N \pi\left[R_{o}^{2}-\left(R_{o}-w\right)^{2}\right] \\
& \eta_{s i v v e r}=\frac{A_{c}-\left(A_{p o, i}+A_{f u u,}\right)}{A_{c}-A_{p o, i}} \\
& \eta_{v g}=\frac{A_{c}-A_{p o, i}}{A_{c}}
\end{aligned}
$$

\section{b- Pie Geometry, Fig. 2(b)}

$$
\begin{aligned}
& h=\sqrt{\left(R_{o}-W\right)^{2}-W^{2}}-W \tan \left[\frac{\pi}{2}-\frac{\pi}{N}\right] \\
& \text { for } 0 \leq \mathrm{y} \leq \mathrm{W}, \\
& \varepsilon=\frac{N}{\pi} \sin ^{-1}\left[\frac{W}{R_{o}-W}\right], \quad \quad \beta=\frac{\pi}{2}+\varepsilon \frac{\pi}{N} \\
& A_{P}(t)=2 N\left\{\begin{array}{l}
\frac{1}{2}(1-\varepsilon) \frac{\pi}{N}\left(R_{o}-W\right)^{2} \\
-\frac{1}{2} W h
\end{array}\right\}+2 N\left\{\begin{array}{l}
\frac{1}{2}(1-\varepsilon) \frac{\pi}{N}\left[\left(R_{o}-W+\int_{0}^{t_{y}} \dot{r}_{f u} d t\right)^{2}-\left(R_{o}-W\right)^{2}\right] \\
+h\left(\int_{0}^{t_{v}} \dot{r}_{f u} d t\right) \\
\left.+\frac{1}{2}\left[\frac{\pi}{2}-\frac{\pi}{N}+\beta\right] \int_{0}^{t y} \dot{r}_{f u} d t\right)
\end{array}\right\} \text { Eq.(7) } \\
& A_{f}(t)=2 N\left\{\frac{1}{2}(1-\varepsilon) \frac{\pi}{N}\left[R_{o}^{2}-\left(R_{o}-W\right)^{2}\right]+h W+\frac{1}{2}\left[\frac{\pi}{2}-\frac{\pi}{N}+\beta\right] W^{2}\right\} \\
& -2 N\left\{\begin{array}{l}
\frac{1}{2}(1-\varepsilon) \frac{\pi}{N}\left[R_{o}^{2}-\left(R_{o}-W+\int_{0}^{t_{v}} \dot{r}_{f u} d t\right)^{2}\right] \\
+h\left(W-\int_{0}^{t_{v}} \dot{r}_{f u} d t\right)+\frac{1}{2}\left[\frac{\pi}{2}-\frac{\pi}{N}+\beta\right]\left(W^{2}-\left(\int_{0}^{t_{v}} \dot{r}_{f u} d t\right)^{2}\right)
\end{array}\right\}
\end{aligned}
$$


Military Technical College

Kobry El-Kobbah,

Cairo, Egypt

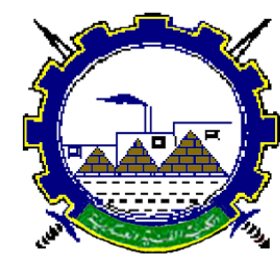

I.C.E.E.2016 $8^{\text {th }}$ International Conference

on

Chemical \& Environmental

Engineering

$19-21$ April 2016

c- Triangular Geometry, Fig. 2(c)

$$
\begin{aligned}
& h=\sqrt{\left(R_{o}-W\right)^{2}-W^{2}}-W \tan \left(\frac{\pi}{2}-\frac{\pi}{N}\right), \quad \varepsilon=\frac{N}{\pi} \sin ^{-1}\left(\frac{W}{R_{o}-W}\right), \text { and } \quad \beta=\frac{\pi}{2}+\varepsilon \frac{\pi}{n} \\
& 0 \leq y=\int_{0}^{t_{y}} \dot{r}_{f u} d t \leq W \\
& A_{p}(t)=N\left(h^{2} \sin \frac{\pi}{N} \cos \frac{\pi}{2}\right)+2 N\left(\left(\int_{0}^{t_{v}} \dot{r}_{f u} d t\right) h \sin \frac{\pi}{N}+h\left(\int_{0}^{t_{v}} \dot{r}_{f u} d t\right)+\frac{1}{2} \pi\left(\int_{0}^{t y} \dot{r} f u d t\right)\right. \\
& A_{f}(t)=2 N\left[h W \sin \left(\frac{\pi}{N}\right)+h w+\frac{1}{2}\left[\left(\frac{\pi}{2}-\varepsilon \frac{\pi}{N}+\beta\right) W^{2}\right]\right] \\
& -2 N\left[\begin{array}{c}
h\left(W-\int_{0}^{t_{v}} \dot{r}_{f u} d t\right) \sin \left(\frac{\pi}{N}\right)+h\left(w-\int_{0}^{t_{v}} \dot{r}_{f u} d t\right) \\
+\frac{1}{2}\left[\left(\frac{\pi}{2}-\varepsilon \frac{\pi}{N}+\beta\right)\left(W^{2}-\left(\int_{0}^{t_{v}} \dot{r}_{f u} d t\right)^{2}\right)^{2}\right]
\end{array}\right]
\end{aligned}
$$

Where: $\quad w=R_{o}-R_{i}, \quad \mathrm{R}_{\mathrm{i}}=\frac{d_{p o}}{2} \quad y=\int_{0}^{t_{y}} \dot{r}_{f u} d t$

$\mathrm{A}_{\mathrm{c}}$ initial area of combustion chamber, $\mathrm{i}$ initial value, $\mathrm{t}_{\mathrm{y}}$ operating time and $\dot{r}_{f u}$ solid fuel regression rate.

When a large number of ports are used in the grain design, they can be simplified from a pie geometry to triangular port. This reduces the cost of constructing the casting mandrels $[1,3]$. The corners of the ports are usually rounded because of stress considerations; this also has been incorporated into the geometry.

\section{2-2. Fuel Grain Surface Crack Phenomena}

The HRM regression rate is dependent upon the interrelationships between the heat transfer phenomena (convection and radiation) and fuel grain geometry during burning time. The regression rate occurs in a burning surface thin sheet of melted solid fuel within the complete combustion of turbulent flame zone during combustion boundary layer. Hybrid combustion processes are driven by convective and radiative heat transfer from the flame zone over the fuel grain surface. In the case of a crack on the surface of fuel grain, the flow rate of the gases (or heat transfer) to the crack surface is very slow with respect to the actual burning surface, so the resulting combustion occurs at a slower rate over the crack surface than at the actual (normal) fuel grain surface. These cracks are slowly eroded away with burning time, reducing 
Military Technical College

Kobry El-Kobbah,

Cairo, Egypt

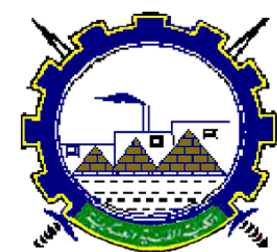

I.C.E.E.2016 $8^{\text {th }}$ International Conference

on

Chemical \& Environmental

Engineering

$19-21$ April 2016

the potential for detonation as shown in Fig. (3). However, while regression rate is much sensitive to $A_{p o}$, it is insensitive to cracks.

\section{Selection Criteria of Hybrid Propellant}

The designer of hybrid propulsion system (HPS) first selects a propellant type from a large variety of operational propellants. Those are presently available for a wide range of storability, specific impulses, densities, regression rates, mechanical and safety or hazard properties as well as environmental capabilities.

Factors of performance, safety, operability and cost need to be considered for any given application. Generally, the development, production and operation costs of the system play a major role in the selection of the propellant combination.

\subsection{Oxidizer Selection}

For propulsive stage applications, an ideal hybrid oxidizer should have the following characteristics:

- Storability,

- Handling and launch safety,

- Availability,

- Ease of ignition,

- Environmentally friendly combustion products.

The most regular propulsion oxidizer items are described in Table (1). Almost all those oxidizers have been experimentally tested at liquid propulsion systems.

The $\mathrm{H}_{2} \mathrm{O}_{2}$, with concentration over $85 \%$, is projected as oxidizer for space applications [6], passing through a suitable catalyst, $\mathrm{H}_{2} \mathrm{O}_{2}$ decomposes into super heated steam $\left(>500^{\circ} \mathrm{C}\right)$ and oxygen, at which combustion is spontaneous with most conventional fuels.

Cryogenic LOX is not suitable for space propulsion because of the problems of long-term storability. $\mathrm{N}_{2} \mathrm{O}_{4}$ appears to be a likely candidate because of its wide availability in the space industry. Unfortunately, as a hybrid oxidizer it is less desirable because of its toxicity and ignition problems [6].

$\mathrm{N}_{2} \mathrm{O}$ (laughing gas) has the additional advantage of being potentially "self-pressurizing" due to its very low vapor pressure, low cost and readily available oxidizer, . Table (2) introduces the handling and storage characteristics of hybrid oxidizers [3]. Table (3) compares the advantages and disadvantages of common oxidizers used with HRM. 
Military Technical College

Kobry El-Kobbah,

Cairo, Egypt

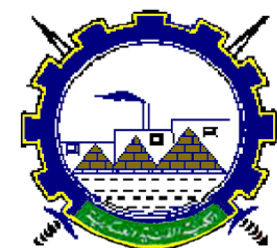

I.C.E.E.2016 $8^{\text {th }}$ International Conference

on

Chemical \& Environmental

Engineering

$19-21$ April 2016

Table (1) Physical properties of normal hybrid oxidizers [4,5]

\begin{tabular}{l|c|c|c|c|c}
\hline \multicolumn{1}{c|}{ Name (Formula) } & $\begin{array}{c}\text { Molecular } \\
\text { weight, } \\
\text { g/mol }\end{array}$ & $\begin{array}{c}\text { Melting } \\
\text { point, K }\end{array}$ & $\begin{array}{c}\text { Boiling } \\
\text { point, } \\
\text { K }\end{array}$ & $\begin{array}{c}\text { Density, } \\
\mathbf{k g} / \mathbf{m}\end{array}$ & $\begin{array}{c}\text { Heat of } \\
\text { formation } \\
\text {, kJ/mol }\end{array}$ \\
\hline \hline Nitric acid $\left(\mathrm{HNO}_{3}\right)$ & 63.02 & 232 & 359 & 1520 & 173 \\
Nitrogen tetraoxide $\left(\mathrm{N}_{2} \mathrm{O}_{4}\right)$ & 92.02 & 262 & 294 & 1450 & 28 \\
Hydrogen peroxide $\left(\mathrm{H}_{2} \mathrm{O}_{2}\right)$ & 34.02 & 274 & 424 & 1448 & 187 \\
Chlorine trifluoride $\left(\mathrm{CLF}_{3}\right)$ & 92.46 & 197 & 285 & 1895 & 186 \\
Liquid oxygen, $\mathrm{LOx}\left(\mathrm{O}_{2}\right)$ & 32.0 & 54 & 90 & 1144 & 13 \\
Fluorine $\left(\mathrm{F}_{2}\right)$ & 38.0 & 54 & 85 & 1505 & 13 \\
\hline Gaseous oxygen $\left(\mathrm{O}_{2}\right)$ & 31.99 & 55 & 91 & 1.98 & zero \\
Gaseous Nitrous oxide $\left(\mathrm{N}_{2} \mathrm{O}\right)$ & 44.01 & 51 & 88 & 1.43 & 81.8 \\
\hline \hline
\end{tabular}

Table (2) Handling and storage characteristics of the hybrid oxidizers

\begin{tabular}{l|l|l|l|l}
\hline \hline \multicolumn{1}{c|}{ Oxidizer } & \multicolumn{1}{|c|}{$\begin{array}{c}\text { Thermal } \\
\text { stability }\end{array}$} & Handling hazard & Storability & \multicolumn{1}{c}{$\begin{array}{c}\text { Materials } \\
\text { Compatibility }\end{array}$} \\
\hline \hline $\begin{array}{l}\text { Liquid } \\
\text { Oxygen, Lox } \\
\left(\mathrm{O}_{2}\right)\end{array}$ & Good & Good & Cryogenic & $\begin{array}{l}\text { AL, SS, Nickel } \\
\text { alloys, Copper, } \\
\text { Teflon }\end{array}$ \\
\hline $\begin{array}{l}\mathrm{Hydrazine} \\
\left(\mathrm{N}_{2} \mathrm{O}_{4}\right)\end{array}$ & $\begin{array}{l}\text { Decomposes } \\
\text { above 125 K }\end{array}$ & $\begin{array}{l}\text { Very toxic, hazier } \\
\text { douse skin contact }\end{array}$ & $\begin{array}{l}\text { Good, Should be } \\
\text { kept anhydrous }\end{array}$ & $\begin{array}{l}\text { Al, SS, Nickel, } \\
\text { Teflon }\end{array}$ \\
\hline $\begin{array}{l}\text { Red or White } \\
\text { Nitric acid, } \\
(\mathrm{HNO})\end{array}$ & Good & $\begin{array}{l}\text { Very toxic, hazier } \\
\text { douse skin contact }\end{array}$ & Corrosive & $\begin{array}{l}\text { AL, SS, Teflon, } \\
\text { polyethylene }\end{array}$ \\
\hline $\begin{array}{l}\mathrm{Hydrogen} \\
\text { Peroxide, } \\
\left(85 \% \mathrm{H}_{2} \mathrm{O}_{2}\right)\end{array}$ & $\begin{array}{l}\text { Decomposes } \\
\text { above 500 C }\end{array}$ & $\begin{array}{l}\text { toxic, hazier douse } \\
\text { skin contact }\end{array}$ & $\begin{array}{l}\text { Deteriorates at } \\
1 \% \text { per year }\end{array}$ & $\begin{array}{l}\text { AL, SS, Teflon, } \\
\text { polyethylene }\end{array}$ \\
\hline $\begin{array}{l}\text { Nitrous Oxide, } \\
\left(\mathrm{N}_{2} \mathrm{O}\right)\end{array}$ & $\begin{array}{l}\text { Decamp } \\
\text { above 500C }\end{array}$ & Good & Good & $\begin{array}{l}\text { AL, SS, Teflon, } \\
\text { polyethylene }\end{array}$ \\
\hline $\begin{array}{l}\text { Liquid } \\
\text { Fluorine, } \\
\left.(\mathrm{LF})_{2}\right)\end{array}$ & Good & $\begin{array}{l}\text { Toxic, reactive with } \\
\text { many metals }\end{array}$ & Cryogenic & $\begin{array}{l}\text { AL, SS, nickel } \\
\text { alloys, Brass }\end{array}$ \\
\hline
\end{tabular}


Military Technical College Kobry El-Kobbah, Cairo, Egypt

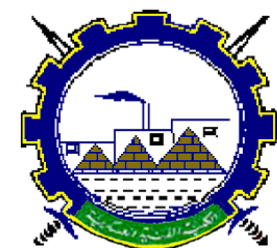

I.C.E.E.2016 $8^{\text {th }}$ International Conference

on

Chemical \& Environmental

Engineering

$19-21$ April 2016

Table 3 Advantages and disadvantages of hybrid oxidizers

\begin{tabular}{|c|c|c|}
\hline Oxidizer & Advantages & Disadvantages \\
\hline $\begin{array}{l}\text { Gaseous oxygen } \\
\left(\mathrm{GO}_{2}\right)\end{array}$ & $\begin{array}{l}\text {-Cheap } \\
\text {-Readily available } \\
\text {-Safe to handle and store } \\
\text {-Compatibility with most materials } \\
\text {-No specialized equipment required }\end{array}$ & $\begin{array}{l}\text {-Low density } \\
\text {-Multiple ignition devices } \\
\text { required for repeatable } \\
\text { ignition or short off time } \\
\text { between re-start. }\end{array}$ \\
\hline $\begin{array}{l}\text { Liquid oxygen } \\
\left(\mathrm{LO}_{2}\right)\end{array}$ & $\begin{array}{l}\text {-High density } \\
\text {-Most active oxidizer }\end{array}$ & $\begin{array}{l}\text {-Cryogenic } \\
\text {-Required compatible } \\
\text { components } \\
\text {-Handling and storage } \\
\text { difficulties }\end{array}$ \\
\hline $\begin{array}{l}\text { Hydrogen } \\
\text { Peroxide } \\
\left(\mathrm{H}_{2} \mathrm{O}_{2}\right)\end{array}$ & $\begin{array}{l}\text {-Catalytic decomposition into hot steam } \\
\text { + oxygen means no external ignition } \\
\text { required } \\
\text {-Re-startable operation }\end{array}$ & $\begin{array}{l}\text {-Storage difficulties } \\
\text {-Potential run-away } \\
\text { decomposition } \\
\text {-Explosive }\end{array}$ \\
\hline $\begin{array}{l}\text { Nitrogen } \\
\text { Tetroxide } \\
\left(\mathrm{N}_{2} \mathrm{O}_{4}\right)\end{array}$ & -Energetic oxidizer & -Handling difficulties \\
\hline
\end{tabular}

\section{3-2 Fuel Selection}

The most common solid fuels may be subdivided into the following groups [7]:

- Traditional solid fuel as:

- Plastic materials (polyethylene, PE, and polymethylacrelate, PMMA),

- Rubbers (HTBP)

- New generation solid fuel as:

○ hydrocarbon materials (paraffin)

o others as Beeswax and Lard.

The physical properties of typical solid fuels used with HRM are listed in Table (4). Those fuels are generally not found in pure form, but as mixtures to obtain the desired combustion, ignition and physical properties. 
Military Technical College

Kobry El-Kobbah,

Cairo, Egypt

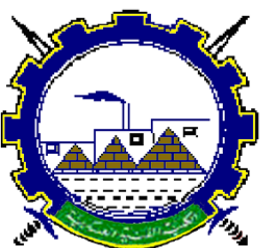

I.C.E.E.2016 $8^{\text {th }}$ International Conference

on

Chemical \& Environmental

Engineering

$19-21$ April 2016

Table (4) Physical properties of common hybrid fuels [4,5]

\begin{tabular}{l|l|l|l|l|l|l}
\hline \multicolumn{1}{c|}{ Parameters } & \multicolumn{1}{c|}{ PMMA } & \multicolumn{1}{c|}{ PE } & \multicolumn{1}{c|}{ HTPB } & Paraffin & Beeswax & Lard \\
\hline \hline Molecular formula & $\mathrm{C}_{5} \mathrm{H}_{8} \mathrm{O}_{2}$ & $\mathrm{C}_{2} \mathrm{H}_{4}$ & $\mathrm{C}_{10} \mathrm{H}_{15.5} \mathrm{O}_{0.07}$ & $\mathrm{C}_{25} \mathrm{H}_{52}$ & $\mathrm{C}_{46} \mathrm{H}_{92} \mathrm{O}$ & $\begin{array}{l}\mathrm{C}_{15} \mathrm{H}_{26} \\
\mathrm{O}_{6}\end{array}$ \\
\hline $\begin{array}{l}\text { Molecular } \\
\text { weight }(\mathrm{g} / \mathrm{mol})\end{array}$ & 100.12 & 28.05 & 138 & 352 & & \\
\hline Density $\left(\mathrm{Kg} / \mathrm{m}^{3}\right)$ & 1180 & 940 & 930 & 900 & 961 & 649 \\
\hline Melting point $(\mathrm{C})$ & $130-140$ & 130 & --- & $42-72$ & $62-64$ & \\
\hline $\begin{array}{l}\text { Heat of combustion } \\
\text { (kJ/gm) }\end{array}$ & 26.02 & 46.4 & 46.5 & 45.6 & & \\
\hline $\begin{array}{l}\text { Standard heat of } \\
\text { formation }(\mathrm{KJ} / \mathrm{mol})\end{array}$ & -430.5 & -58.6 & -51.8 & -459.8 & -823.9 & $\begin{array}{l}1040 . \\
6\end{array}$ \\
\hline
\end{tabular}

Plexiglas or PMMA, originally, most of the work on combustion laboratory research used PMMA. Its low cost, more safety, good machinability, easy accessibility and transparency make it good for demonstration models.

PE, It is initially chosen as a solid fuel for HPS application in upper-space [6] because of its good machinability, low cost, acceptable performance, long storage without any change of physical and chemical properties and easiness to obtain. The PE is an extremely low cost fuel as compared with HTPB and PMMA.

HTPB, It is a rubber component. At present, it is the most popular fuel to use in hybrid firings that is quite energetic, high regression rate and extremely safe to handle. Studies show that HTPB soaked in liquid oxygen is not explosive [3].

However, a main disadvantage of using HTPB in HRM practical work is the high smoke content in exhaust gases. This would result in easy detection of the flying missile.

Paraffin wax is hydrocarbons with the general formula $\mathrm{C}_{n} \mathrm{H}_{2 n+2}$. With carbon chain varieties in the $20 \leq \mathrm{n} \leq 40$ ranges, solid state at room temperature with a typical low melting point $\left(\approx 50^{\circ} \mathrm{C}\right)$.

Paraffin and Beeswax have a numbers of distinct advantages over HTPB, PE and PMMA, these are as follows:

- the ability to achieve a number of complex shapes as HTPB,

- as Paraffin and Beeswax sublime at a quicker rate than PE and PMMA, so the regression rate is higher than PE and PMMA by 3-4 times and still greater then HTPB fuel, 
Military Technical College

Kobry El-Kobbah,

Cairo, Egypt

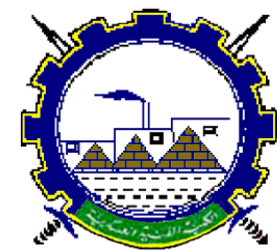

I.C.E.E.2016 $8^{\text {th }}$ International Conference

on

Chemical \& Environmental

Engineering

$19-21$ April 2016

- during its manufacturing processes a number of additives may be incorporated into the molding operation to achieve a higher thermal resistance and to increase performance,

- Paraffin has energy the same as a kerosene (per unit mass), but density $17 \%$ greater.

The main requirements for new hybrid solid fuel are:

- easy to manufacturing, casting with low cost,

- good mechanical properties to ignition and operation pressures,

- maximum density, heat of formation, specific impulse and regression rate,

- long term storage in space with good thermal stability,

Table (5) compares the advantages and disadvantages of common solid fuels, used with HPS.

\section{3-3. Solid-Fuel Additives Selection}

The criteria for selection of additives to be used with solid fuel are mainly, its heat of combustion, physical properties, high thermal conductivity, low specific heat, low latent heat of fusion, low density, and melting point suitable relative to the fuel surface temperature.

Table (5) Advantages and disadvantages of the common solid fuels.

\begin{tabular}{|c|c|c|}
\hline Hybrid Fuel & Advantages & Disadvantages \\
\hline Polyethene (PE) & $\begin{array}{l}\text { - Cheap } \\
\text { - Readily available } \\
\text { - Safe and inert } \\
\text { - Simple to machine }\end{array}$ & - Less energetic fuel \\
\hline $\begin{array}{l}\text { Polymethyl methacrylate } \\
\text { (PMMA) }\end{array}$ & $\begin{array}{l}\text { - Cheap, } \\
\text { - Transparent for combustion, } \\
\text { - Readily available, } \\
\text { - Safe and inert, } \\
\text { - Simple to machine. }\end{array}$ & $\begin{array}{l}\text { - Can suffer cracking under } \\
\text { thermal stress in large } \\
\text { engines } \\
\text { - Less energetic fuel. }\end{array}$ \\
\hline $\begin{array}{l}\text { Hydroxyl-terminated } \\
\text { polybutadiene (HTPB) }\end{array}$ & $\begin{array}{l}\text { - Easily moulded to shape, } \\
\text { - Additives simple to add, } \\
\text { - Suitable for all motor sizes, } \\
\text { - High density. }\end{array}$ & $\begin{array}{l}\text { - Smoke in exhaust gas, } \\
\text { - New mould required for } \\
\text { each different design. }\end{array}$ \\
\hline $\begin{array}{l}\text { Waxes (Paraffin and } \\
\text { Beeswax) }\end{array}$ & $\begin{array}{l}\text { - Cheap, } \\
\text { - Clean exhaust, } \\
\text { - Readily available, } \\
\text { - Safe and inert, } \\
\text { - Easily moulded to shape, } \\
\text { - Additives simple to add, }\end{array}$ & $\begin{array}{l}\text { - low melting point, } \\
\text { - throat nozzle blocking } \\
\text { during operation. }\end{array}$ \\
\hline
\end{tabular}


Military Technical College

Kobry El-Kobbah,

Cairo, Egypt

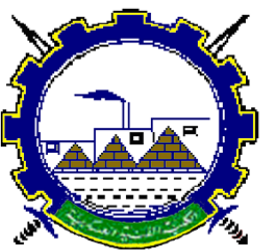

I.C.E.E.2016 $8^{\text {th }}$ International Conference

on

Chemical \& Environmental

Engineering

$19-21$ April 2016

Generally, adding metal particles to fuel grain material increases combustion temperature lading to enhance performance, However, the metal usually also increase the mean molecular weight of the combustion gases which tends to decrease performance specially specific impulse. Therefore, only metals with a low molecular weight are usually applied.

For the solid fuel material, the following metals, solid oxidizer and others were considered as possible additives: Lithium (Li), Beryllium (Be), Boron (B), Magnesium (Mg), Aluminum (AL), Ammonium Per-chlorate (AP), Ammonium nitrate (AN), black carbon and copper.

The influences of these metal additives were compared using thermo-chemical calculation [5]. Table (6) shows thermodynamic and physical properties of several energetic additives.

Table (6) Physical and thermodynamic properties of common energetic additives. [4,5]

\begin{tabular}{|c|c|c|c|c|c|c|c|}
\hline \multirow{2}{*}{ Fuel } & \multicolumn{2}{|c|}{$\begin{array}{c}\text { Virgin material } \\
\text { properties }\end{array}$} & \multirow{2}{*}{$\begin{array}{c}\text { Gravimetr } \\
\text { ic heat of } \\
\text { oxidation } \\
\text { kJ/gm fuel }\end{array}$} & \multirow{2}{*}{$\begin{array}{c}\text { volumetric } \\
\text { heat of } \\
\text { oxidation } \\
\mathbf{k J} / \mathrm{cm}^{3}\end{array}$} & \multirow{2}{*}{$\begin{array}{l}\text { Final } \\
\text { oxide }\end{array}$} & \multicolumn{2}{|c|}{$\begin{array}{l}\text { Final oxide } \\
\text { properties }\end{array}$} \\
\hline & $\begin{array}{l}\rho \\
\left(\mathrm{gm} / \mathrm{cm}^{3}\right)\end{array}$ & $\begin{array}{l}\mathbf{T}_{\text {melt- }} \\
{ }^{\circ} \mathbf{C}\end{array}$ & & & & $\begin{array}{l}\rho \\
\left(\mathrm{gm} / \mathrm{cm}^{3}\right)\end{array}$ & $\begin{array}{l}\mathbf{T}_{\text {melt }}{ }^{\circ} \\
C\end{array}$ \\
\hline Aluminum (Al) & 2.70 & 660 & 31.1 & 83.9 & $\mathrm{Al}_{2} \mathrm{O}_{3}(\mathrm{~s})$ & 3.97 & 2054 \\
\hline Boron $(\mathrm{B})$ & 2.34 & 2077 & 58.7 & 137.0 & $\mathrm{~B}_{2} \mathrm{O}_{3}(\mathrm{~s})$ & 2.46 & 450 \\
\hline Beryllium (Be) & 1.85 & 1287 & 66.5 & 123.0 & $\mathrm{Be} \mathrm{O}(\mathrm{s})$ & 3.01 & 2530 \\
\hline Iron $(\mathrm{Fe})$ & 7.86 & 1535 & 7.39 & 58.1 & $\mathrm{Fe}_{2} \mathrm{O}_{3}(\mathrm{~s})$ & 5.24 & 1462 \\
\hline Lithium (Li) & 0.534 & 181 & 43.2 & 23.0 & $\mathrm{Li}_{2} \mathrm{O}(\mathrm{s})$ & 2.013 & $>1700$ \\
\hline Magnesium $(\mathrm{Mg})$ & 1.74 & 649 & 24.7 & 43.0 & $\mathrm{Mg} \mathrm{O}(\mathrm{s})$ & 3.58 & 2832 \\
\hline Carbon $(\mathrm{C})$ & 2.25 & 3652 & 32.8 & 73.8 & $\mathrm{CO}_{2}(\mathrm{~g})$ & 0.0019 & -56.6 \\
\hline Silicon (Si) & 2.33 & 1412 & 32.3 & 75.2 & $\mathrm{SiO}_{2}(\mathrm{~s})$ & 2.20 & 1723 \\
\hline Tungsten (W) & 19.35 & 3407 & 4.59 & 88.8 & $\mathrm{WO}_{3}(\mathrm{~s})$ & 7.16 & 1473 \\
\hline
\end{tabular}

Aluminum seems to be the best choice based on its thermal properties, ease of processing, and relatively low cost. However, the existence of $\mathrm{AI}_{2} \mathrm{O}_{3}$ as an inert oxide layer on the external surface of the particle is undesirable and hard to avoid. The amount of active aluminum in the particle depends on the manufacturing process and storage conditions. The sizes of these particles are about micrometers, with the smallest being $2-5 \mu \mathrm{m}$. There are many direct advantages for incorporating nanosized particles into solid fuels and fuel-rich propellants such as:

- Shorter ignition delay.

- More complete combustion in volume-limited propulsion systems.

- Higher particle specific surface area enhancing the rate of heat transfer.

- Greater flexibility in designing new energetic fuels with desirable physical properties. The main advantages of $\mathrm{Al}$ are the relatively high heat of oxidation $(31.1 \mathrm{~kJ} / \mathrm{gm})$, relatively high density $\left(2.7 \mathrm{~g} / \mathrm{cm}^{3}\right)$, and ease of ignition in the hot combustion environment of the rocket motor 
Military Technical College

Kobry El-Kobbah,

Cairo, Egypt

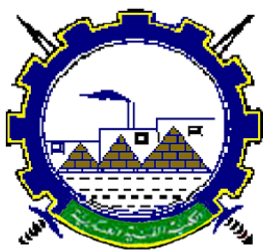

I.C.E.E.2016 $8^{\text {th }}$ International Conference

on

Chemical \& Environmental

Engineering

$19-21$ April 2016

chamber. These properties make $\mathrm{Al}$ an attractive additive for increasing the performance of a propulsion system, especially a volume-limited system.

The mechanism of Al particle combustion is shown in Fig. (4).

\subsection{The Propellant Combination}

The exhaust flow velocity or $\mathrm{I}_{\mathrm{sp}}$ is used to evaluate a chosen propellant combination. Table (7) contains the thermodynamic performance data of some hybrid propellant combinations. It shows also the combustion gases characteristics for the case of equilibrium flow; the combustion and atmospheric pressures are 30 bar and 1 bar respectively.

High-energy liquid oxidizers are often used in the hybrid motors. Addition of metal powders to the hybrid fuel may increase the achievable $\mathrm{I}_{\mathrm{sp}}$., with storable hybrid propellants $\mathrm{I}_{\mathrm{sp}}$ values in the range 250-300 $\mathrm{sec}$ are achievable today and may reach over $350 \mathrm{sec}$ in the future.

It is interesting, to consider the theoretical limit of Isp for chemical propellants. Since $\mathrm{I}_{\mathrm{sp}}$ is proportional to $\sqrt{T_{c} / M}$ one has to look for propellants giving a high flame temperature and low average molecular weight of the combustion products.

Table (7) Theoretical performance of some hybrid propellant combinations [5]

\begin{tabular}{l|l|c|c|c|c|c|c}
\hline \hline Oxidizer & Solid Fuel & $\mathbf{( O / F )}$ & $\begin{array}{c}\text { Isp } \\
(\mathbf{m} / \mathbf{s})\end{array}$ & $\begin{array}{c}\text { Tcch } \\
(\mathbf{K})\end{array}$ & $\begin{array}{c}\mathbf{c}^{*} \\
(\mathbf{m} / \mathbf{s})\end{array}$ & $\begin{array}{c}\mathbf{P} \\
(\mathbf{k g} / \mathbf{m} 3)\end{array}$ & $\begin{array}{c}\mathbf{M} \\
(\mathbf{g} / \mathbf{m o l})\end{array}$ \\
\hline \hline $\mathrm{O}_{2}$ & PMMA & 1 & 2726.8 & 3433.7 & 1798.6 & 2.332 & 21.45 \\
(gas) & PE & 2.5 & 2755.0 & 3534.6 & 1788.9 & 2.4008 & 22.74 \\
& HTPB & 2 & 2733.5 & 3519.2 & 1793.0 & 2.363 & 22.28 \\
\hline $\mathrm{HNO}_{3}$ & PMMA & 2 & 2468.2 & 3142.5 & 1628.1 & 2.863 & 24.11 \\
(Liquid) & PE & 4.4 & 2417.5 & 3049.7 & 1587.8 & 3.033 & 24.79 \\
& HTPB & 4 & 2421.1 & 3117.1 & 1588.7 & 3.034 & 25.34 \\
\hline $\mathrm{H}_{2} \mathrm{O}_{2}$ & PMMA & 2.8 & 2580.1 & 3029.2 & 1694.4 & 2.6612 & 21.60 \\
(Liquid) & PE & 2.2 & 2062.9 & 1484.6 & 1355.4 & 3.8848 & 15.45 \\
& HTPB & 5.4 & 2555.3 & 2976.6 & 1674.6 & 2.7343 & 21.81 \\
\hline \hline
\end{tabular}

Once the possible combinations which meet the performance requirements are established, the selection of oxidizer will be based on handling, storability, transportability, ignition, toxicity, and other parameters. The fuels are all basically handy and non-toxic. Choice of fuel usually depends on cost and the process required for casting the fuel grain. Most of the propellant combinations listed are neither dangerous, toxic nor expensive. The laboratory HRM model for researches, requires propellants that are readily available, reasonably safe, easy to handle and inexpensive. Based on experience, it is recommended to use $\mathrm{GO}_{2}$ or $\mathrm{N}_{2} \mathrm{O}$ as oxidizer and PMMA, PE, Paraffin wax as solid fuels. They give good performance, visible combustion flame and they show high safety as established during experimental work. 
Military Technical College

Kobry El-Kobbah,

Cairo, Egypt

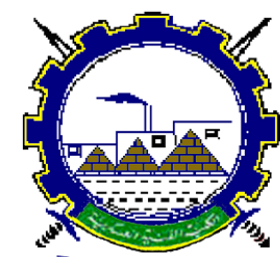

I.C.E.E.2016 $8^{\text {th }}$ International Conference

on

Chemical \& Environmental

Engineering

$19-21$ April 2016

\section{The Fuel Grain Geometry Design}

The fuel grain port geometry is described by fuel grain length $\mathrm{L}_{\mathrm{fu}}$ and the channel port diameter $d_{p o}$, which increases with time at fixed grain length. Since the $A_{b u}$, and the $A_{p o}$ are both dependent on the active channel $\mathrm{d}_{\mathrm{po}}$, the fuel mass flow rate $\dot{m}_{f u}$ will generally change as burning progresses. Both mixture ratio $\mathrm{O} / \mathrm{F}$ and combustion chamber pressure $\mathrm{P}_{\mathrm{c}}$ will therefore vary with time.

At steady state operation, the mass conservation implies

$$
\frac{P_{c} A_{t h}}{c^{*}}=\dot{m}_{o x}+a\left(\frac{\dot{m}_{o x}}{A_{p o}}\right)^{n} L_{f u}^{m} A_{b u} \rho_{f u}
$$

Where $\mathrm{a}, \mathrm{n}$ are regression rate constants and $\mathrm{A}_{\mathrm{th}}$ nozzle throat diameter.

Considering a fixed oxidizer flow rate $\dot{m}_{o x}$ in this equation, the term $A_{b u} A_{p o}^{-n}$ is varying with firing time, and in consequence the operating parameters $\left(\mathrm{P}_{\mathrm{c}}, \mathrm{O} / \mathrm{F}\right.$ and characteristic velocity $\left.\mathrm{c}^{*}\right)$ would change accordingly. All other effects should, therefore, be understood as a consequence of this consideration.

For a hollow cylinder grain of length $\mathrm{L}_{\mathrm{fu}}$, the geometric parameters are;

$$
\left.\begin{array}{l}
A_{p o}=\left(\frac{\pi}{4}\right) d_{p o}^{2} \\
A_{b u}=\pi d_{p o} L_{f u}
\end{array}\right\}
$$

Therefore,

$$
A_{b u} A_{p o}^{-n}=\text { constant } d_{p o}^{1-2 n}
$$

It follows from Eq. (13) that in the case of a cylindrical port grain, if no change of the operating point is required, the oxidizer mass flux exponent $\mathrm{n}$ should be equal to 0.5 .

\section{4-1 Prediction of Port Diameter Variation}

To predict the actual $d_{\mathrm{po}}$ at a given time, let us consider the simple case of constant $\dot{m}_{o x}$, and the fuel regression rate $\dot{r}_{f u}$ equation as:

$$
\dot{r}_{f u}=a G_{o x}^{n} L_{f u}^{m}=\frac{1}{2} \frac{d}{d t} d_{p o}=a\left(\frac{4 \dot{m}_{o x}}{\pi d_{p o}^{2}}\right)^{n} L_{f u}^{m}
$$

The change of $d_{p o}$ with operating time may be predicted as follows

$$
\int_{d_{p o, i}}^{d_{p o}} d_{p o}^{2 n} d d_{p o}=2 a\left(\frac{4 \dot{m}_{o x}}{\pi}\right)^{n} L_{f u}^{m} \int_{0}^{t_{b u}} d t
$$


Military Technical College

Kobry El-Kobbah,

Cairo, Egypt

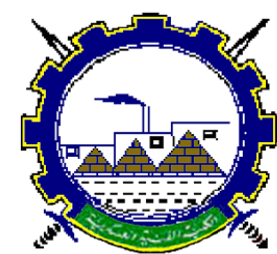

I.C.E.E.2016 $8^{\text {th }}$ International Conference

on

Chemical \& Environmental

Engineering

19-21 April 2016

The general expression for the instantaneous diameter of the circular port grain as

$$
d_{p o}(t)=\left[2 a(2 n+1)\left(\frac{4 \dot{m}_{o x}}{\pi}\right)^{n} L_{f u}^{m} t+d_{p o, i}^{(2 n+1)}\right]^{\frac{1}{2 n+1}}
$$

\section{4-2 Prediction of Fuel Grain Length}

The fuel mass flow can be described at any point of active channel during firing time as

$$
\dot{\mathrm{m}}_{\mathrm{fu}}(\mathrm{x}, \mathrm{t})=\int_{0}^{\mathrm{t}} \int_{0}^{\mathrm{x}} \rho_{\mathrm{fu}} \dot{\mathrm{r}}_{\mathrm{fu}}(\mathrm{x}, \mathrm{t}) \mathrm{P}(\mathrm{x}, \mathrm{t}) \mathrm{dxdt}
$$

Where: $\mathrm{P}$ is the fuel grain channel port perimeter. Then using eq. (14) to predict fuel grain length as a function of initial parameters as

$$
L_{f u}=\left[\left(\frac{\dot{m}_{f u(i)} \pi^{n-1}}{a\left(4\left(\dot{m}_{o x}+\dot{m}_{f u}\right)\right)^{n} \rho_{f u}}\right) d_{p o, i}^{(2 n-1)}\right]^{\frac{1}{m+1}}
$$

\section{4-3 Selection Of Grain Configuration}

The main factors affecting the selection of hybrid solid fuel grain configuration, can be summarized as:

- initial port area,

- grain length-to-diameter ratio,

- required mixture ratio,

- simplicity in production and fabrication cost,

- thrust profile,

- web thickness to satisfy the operating time and

- maximum filling coefficient.

The designer selects a propellant type that is likely to give the required performance, cost, mechanical properties as well as the necessary storage stability and the best safety properties (non-toxic and smokeless).

\section{Performance Investigation}

Comprehensive static tests for small scale hybrid rocket motor have been fired for various solid fuel materials (PMMA, PE, PE+AL, paraffin, bees wax), initial fuel grain diameter is 7 $\mathrm{mm}$, fuel grain length is $100 \mathrm{~mm}$ with gas oxygen as oxidizer as illustrates in Fig. (5).

Pure $\mathrm{PE}$ and $\mathrm{PE}$ with $\mathrm{Al} \%+\mathrm{GO}_{2}$ were the two propellants used for the theoretical performance of the hybrid propellant combustion was studied and discussed, using a standard thermochemical code $\left(\mathrm{I}_{\mathrm{sp}}\right.$ code) [5] as shows in Fig. (6). It was assumed that there is no energy or 
Military Technical College

Kobry El-Kobbah,

Cairo, Egypt

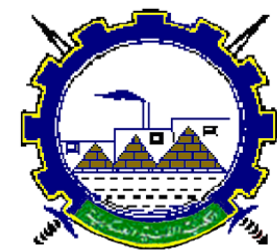

I.C.E.E.2016 $8^{\text {th }}$ International Conference

on

Chemical \& Environmental

Engineering

$19-21$ April 2016

mass transfer to the surroundings. In addition, gases are ideal and that the thermal and dynamic equilibrium between condensed products and the gaseous jet are maintained. The volume of the condensed phase is neglected relative to the gaseous volume. The chemical reaction rates are assumed fast with regards to the residence time in the nozzle. The used equations include chemical reactions, mass conservation, chemical equilibrium and energy conservation. The pressure equations are solved by an iterative technique, based on the Newton-Raphson method.

The stoichometric ratio for $\mathrm{PE}$ with $\mathrm{GO}_{2}$ is 3.4 and performance characterizes $\left(\mathrm{C}^{*}, \mathrm{I}_{\mathrm{sp}}, \mathrm{T}_{\mathrm{c}}, \gamma\right)$ are plotted for different mixture ratios as shown in Fig. (6). It could be seen that, the performance parameters are maximum for $\mathrm{O} / \mathrm{F}=2.3$. Nozzle and measurement instrumentation are used safely by using an oxidizer rich operating zone. Depending on the nature of the propellant, the combustion products will be in the form of molecules $\left(\mathrm{CO}_{2}, \mathrm{CO}, \mathrm{H}_{2} \mathrm{O}, \ldots ..\right)$, free radicals $(\mathrm{C}, \mathrm{H}, \mathrm{O}, \mathrm{CO}, \mathrm{HO} \ldots .$.$) . If the temperature exceeds 5000 \mathrm{~K}$, ionized particles will occur [8].

\section{Conclusion}

HRM is a promising type of space and military propulsion. Many benefits have been demonstrated, like the fact that they can be "green propellant", low cost and safe.

In particular, there are some drawbacks like low regression rate and combustion efficiency.

During the involved firing test, there are an increase in combustion efficiency from $85 \%$ to $95 \%$, and an increase in regression rate of $41 \%$ (with using $\mathrm{Al}$ powder) and $50 \%$ (by using wax material) as solid fuel grain with $\mathrm{GO}_{2}$ as oxidizer.

The fuel charge must be designed in accordance with the particular demands of the required mission. The design includes the dimensions of the solid fuel grain which satisfy minimum shift of mixture ratio, chamber pressure and thrust with operating time more over to satisfy maximum hybrid performances.

For the selection of grain configuration, the main factors, which are to be taken into account, are:

- initial port area,

- grain length-to-diameter ratio,

- required mixture ratio,

- simplicity in production and fabrication cost,

- thrust profile,

- web thickness to satisfy the operating time and

- maximum filling coefficient.

The designer selects a propellant types that is likely to give the required performance, cost and mechanical properties as well as the necessary storage stability and the best hazard properties (e.g.; toxicity and smokeless).

HRP regression rate is much sensitive to fuel grain port channel $\mathrm{A}_{\mathrm{po}}$, it is insensitive to cracks. 
Military Technical College

Kobry El-Kobbah,

Cairo, Egypt

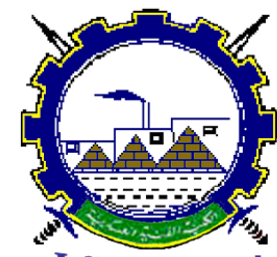

I.C.E.E.2016 $8^{\text {th }}$ International Conference

on

Chemical \& Environmental

Engineering

$19-21$ April 2016

The sliver amount of solid fuel grain in hybrid propulsion system is more than $6 \%$ of total mass of the grain practically; it must be minimized as possible.

The laboratory HRM model for researches, requires propellants that are readily available, reasonably safe, easy to handle and inexpensive. Based on experience, it is recommended to use GO2 as an oxidizer and PMMA as solid fuel grain. They give good performance, visible combustion flame and they show high safety.

After several HRM firing tests, it is clearly shown that the wax (paraffin and beeswax) fuel mixture practically meets all requirements (e.g. higher regression rate and easy ignition), combustion products were very clean, smokeless, environmentally benign, with insignificant instabilities. From manufacturing point of view, this wax mix needs a specific handling. The pure wax fuel grain exhibits some problems during firing as nozzle blocking and its mechanical properties but has high regression rate similar to solid propellants, energetic effectiveness and high degree of safety during manufacturing and combustion. Therefore, based on previous investigation on hybrid propellant, wax material is a good promising solid fuel base material for future development of hybrid propulsion systems.

\section{References}

[1] Smoot, L.D. and Price, C.F., "Regression Rate Mechanisms of Non-Metalized Hybrid Fuel Systems" AIAA, 2nd Aerospace Sciences Meeting, New York, January 25-27, 1965.

[2] Philmon, G., Krishnam, S., Varkey, P.M., Ravindran, M., "Regression Rate and Heat Transfer Corrections For Hybrid Rocket Combustion" Journal of Propulsion and Power, Vol. 17, No. 1, Jan. - Feb. 2001.

[3] Humble, R., Henry, Gary, N. and Larson, Wiley, J., "Propulsion System Analysis and Design" United States Air Force Academy, 1995.

[4] David, R.L., "Hand Book of Chemistry and Physics" International Standard Book Number 0-8493-0596,1995.

[5] Selph, C., "Computer Program For Calculation of Complex Chemical Equilibrium Composition” NASA SP-273, United States Air Force Academy, version, July 1994.

[6] Brown, R and Seller, J.J., "Practical Experience with Hybrid Peroxide Hybrid Rocket" 1st Hydrogen Peroxide Workshop, Guilford, Surrey, 1998.

[7] Ah. El.S Makled "Metalized Fuel Hybrid Rocket Motor Parametric Study" PP-110, ASAT-16, MTC, Cairo, 2015.

[8] David, W, Netzer, "Hybrid Rocket Internal Ballistics" Naval Postgraduate School, Monterey, January 1972. 
Military Technical College

Kobry El-Kobbah,

Cairo, Egypt

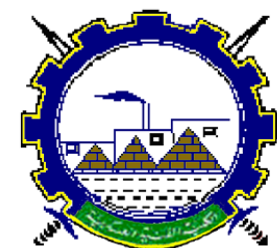

I.C.E.E.2016 $8^{\text {th }}$ International Conference

on

Chemical \& Environmental

Engineering

$19-21$ April 2016

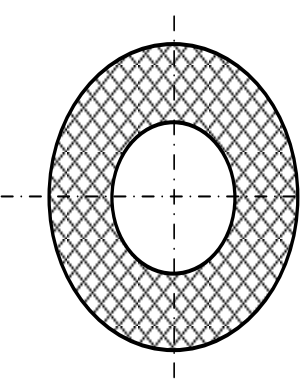

Cylinder

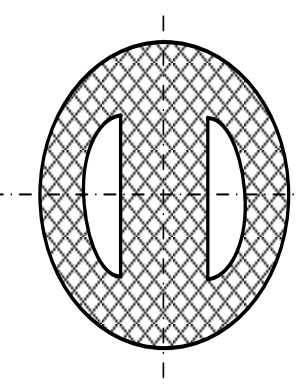

Double-D

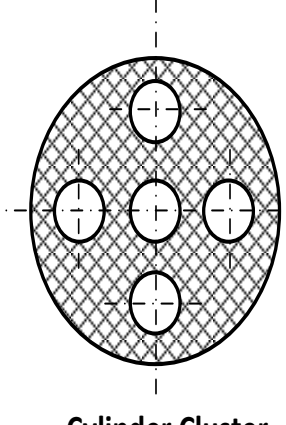

Cylinder Cluster

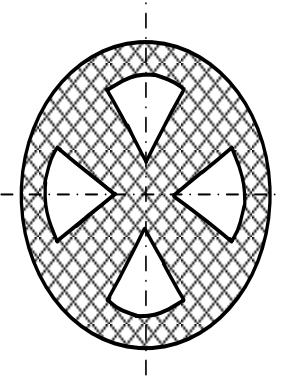

4-Port Wagon Wheel

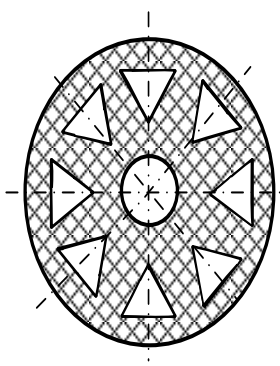

Wagon Wheel

Fig. (1) Cross-section area of fuel grain geometries

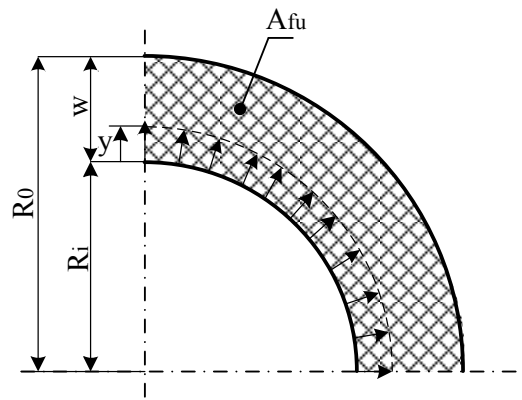

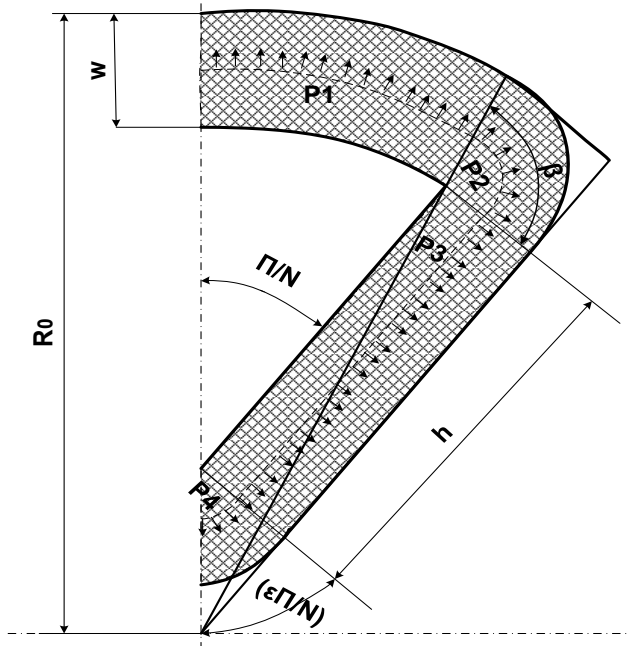

(a) tube geometry

(b) Pie geometry

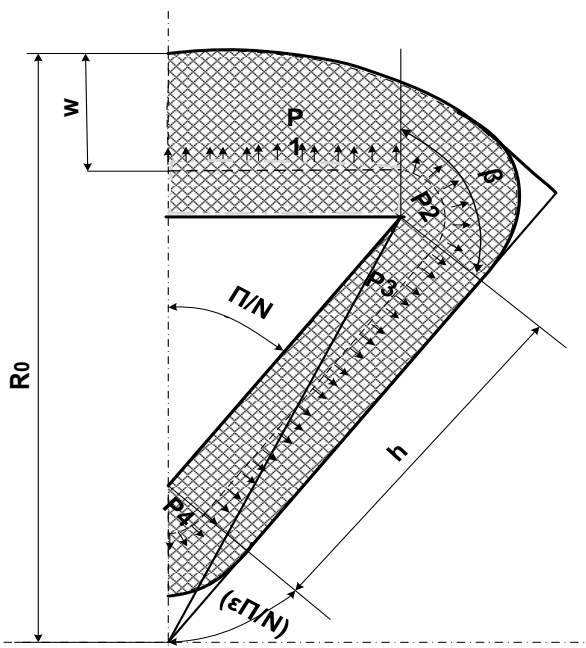

(c) Triangular geometry

Fig. (2) Typical fundamental shapes of fuel grain cross-section 
Military Technical College

Kobry El-Kobbah,

Cairo, Egypt

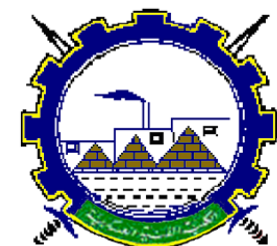

I.C.E.E. 2016 $8^{\text {th }}$ International Conference

on

Chemical \& Environmental

Engineering

$19-21$ April 2016
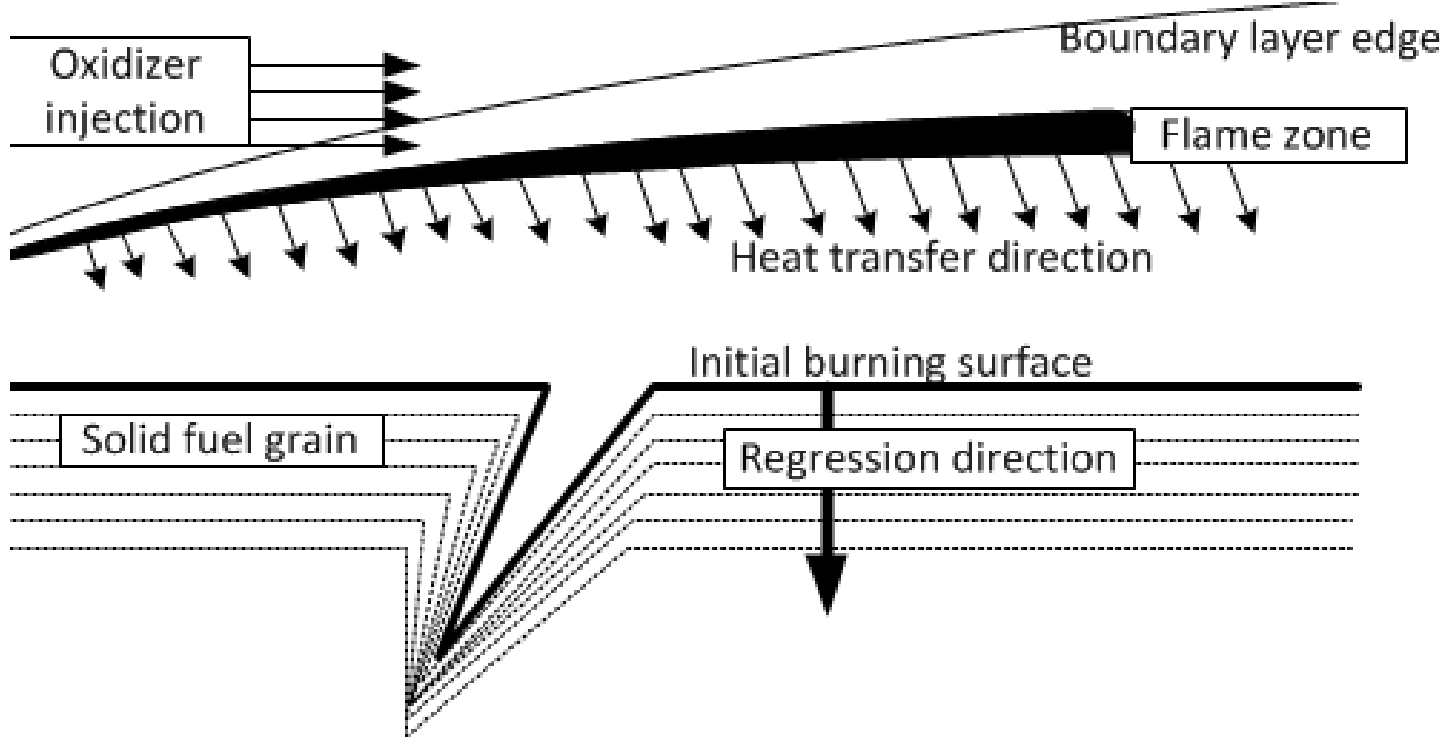

Fig. (3) Solid fuel grain crack regression in hybrids
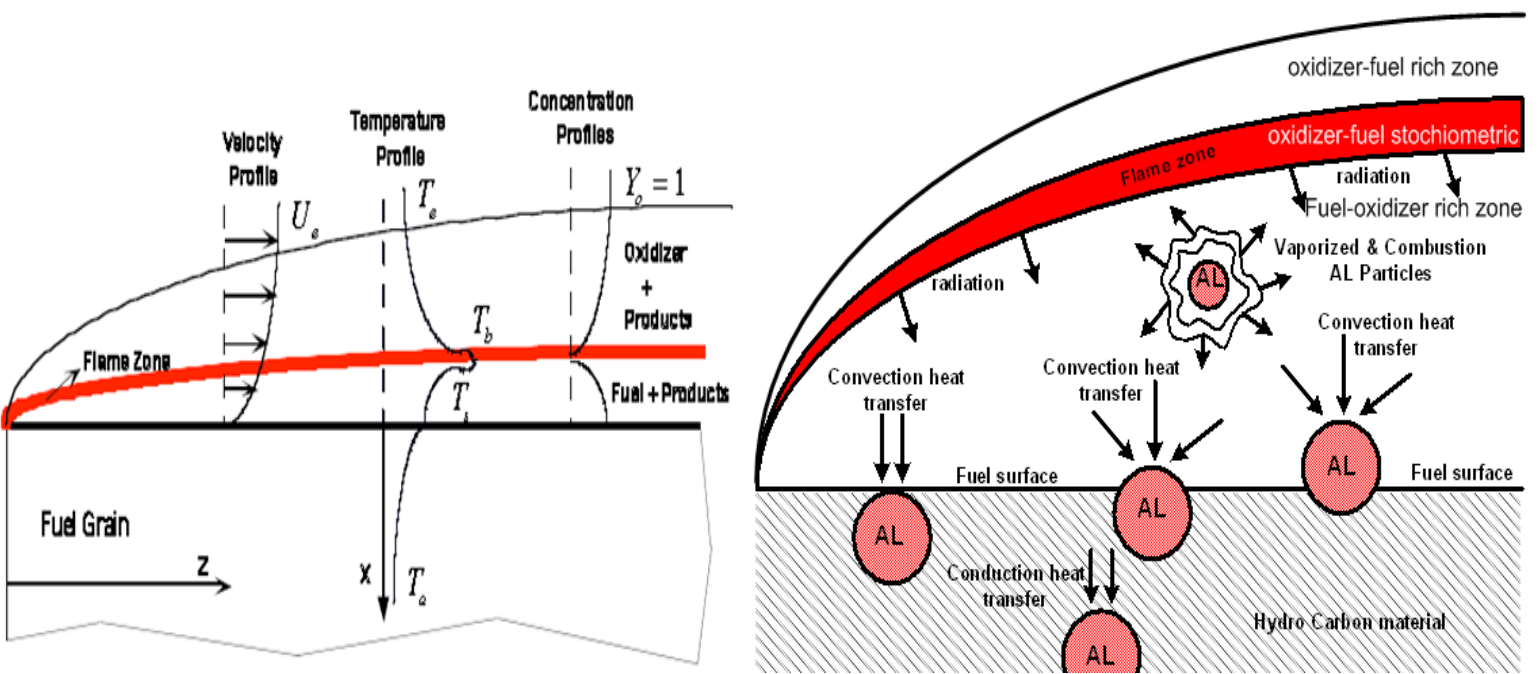

Fig. (4) Al Particle Combustion Mechanism Model Process 
Military Technical College Kobry El-Kobbah,

Cairo, Egypt

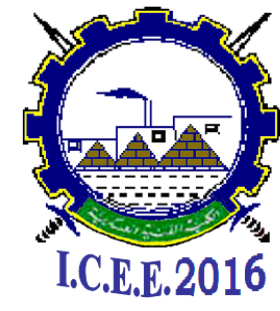

$8^{\text {th }}$ International Conference

on

Chemical \& Environmental

Engineering

$19-21$ April 2016

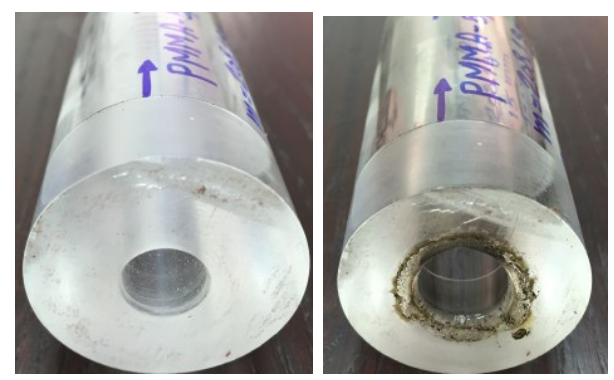

Before and after firing PMMA charge
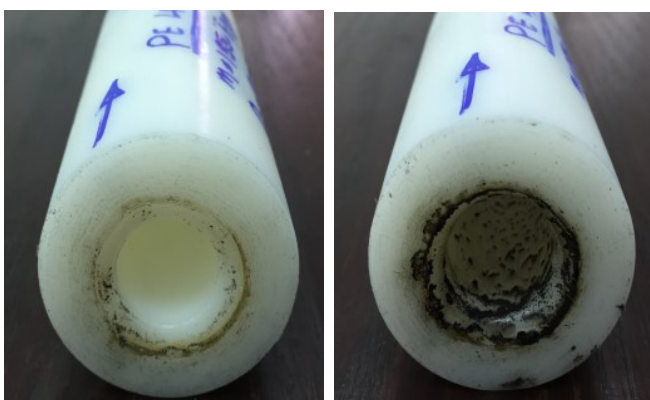

Before and after firing PE charge
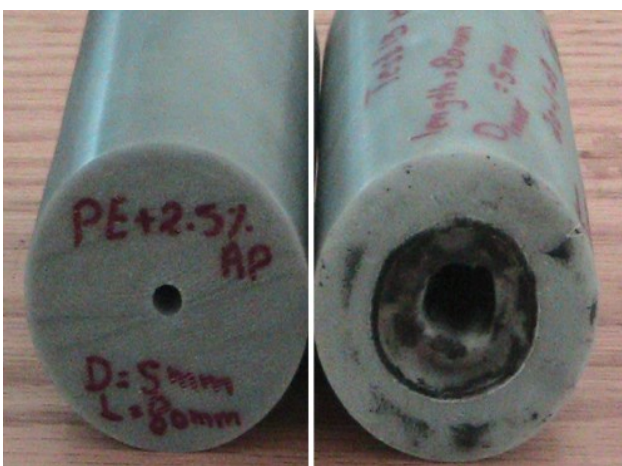

Before and after firing $\mathrm{AL}+\mathrm{PE}$ charge

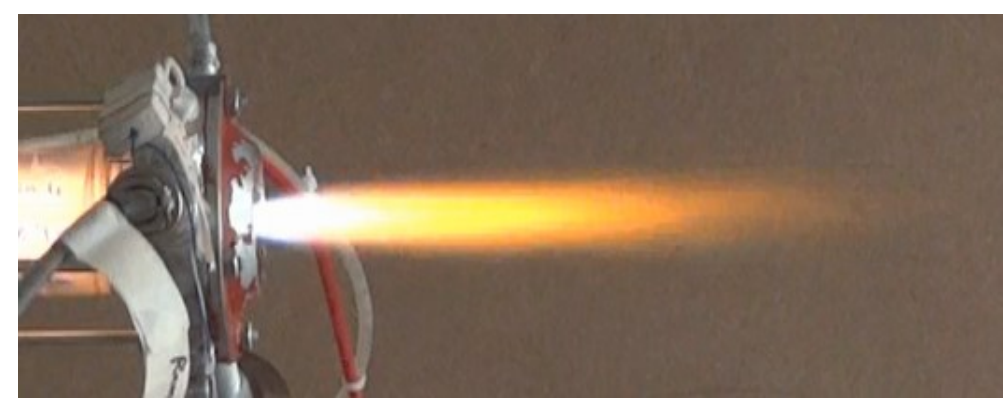

a) PMMA + GO2 firing HRM

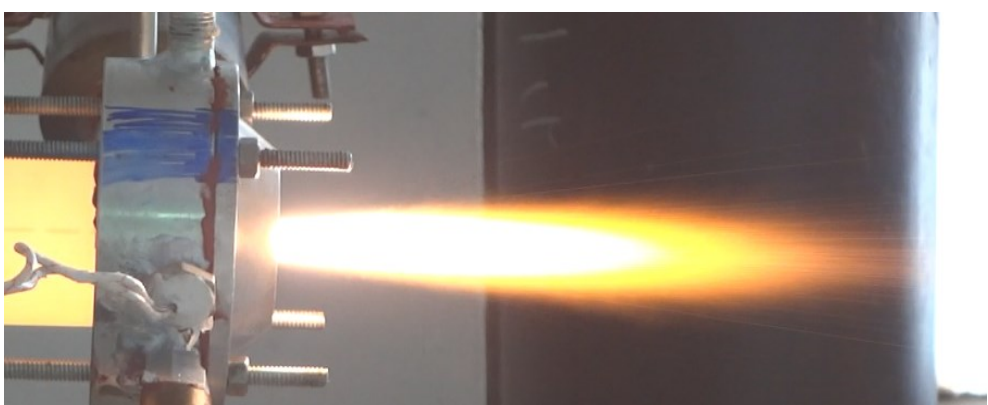

b) PE + GO2 firing HRM

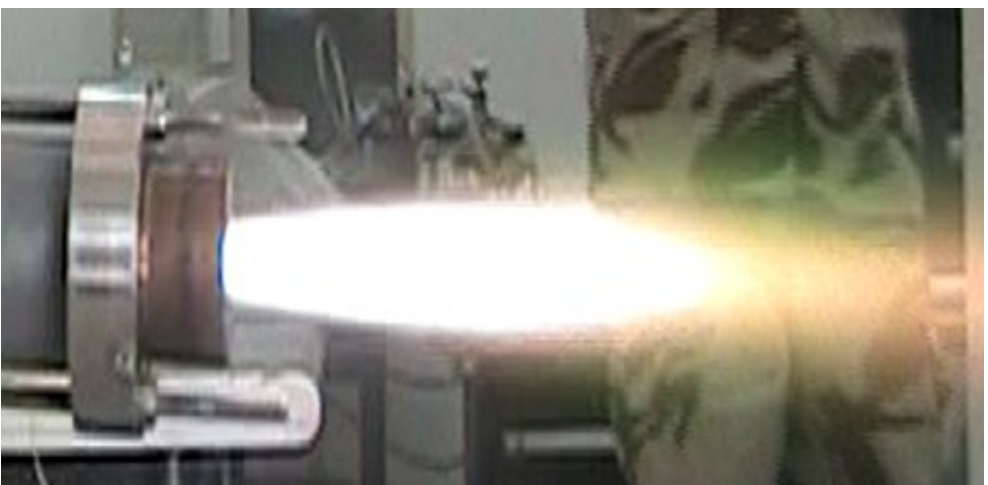

c) $\mathrm{AL}+\mathrm{PE}+\mathrm{GO2}$ firing HRM 
Military Technical College

Kobry El-Kobbah,

Cairo, Egypt

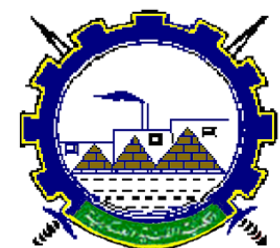

I.C.E.E.2016 $8^{\text {th }}$ International Conference

on

Chemical \& Environmental

Engineering

19-21 April 2016

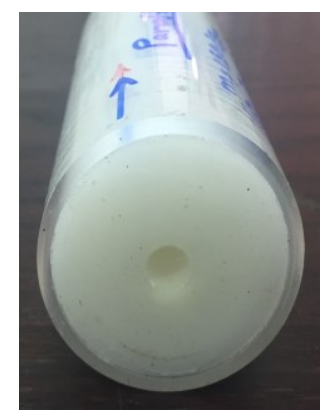

Before and after firing paraffin charge

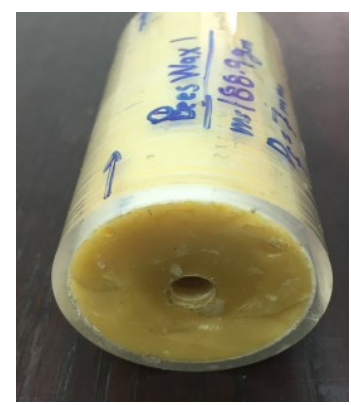

Before and after firing Beeswax charge
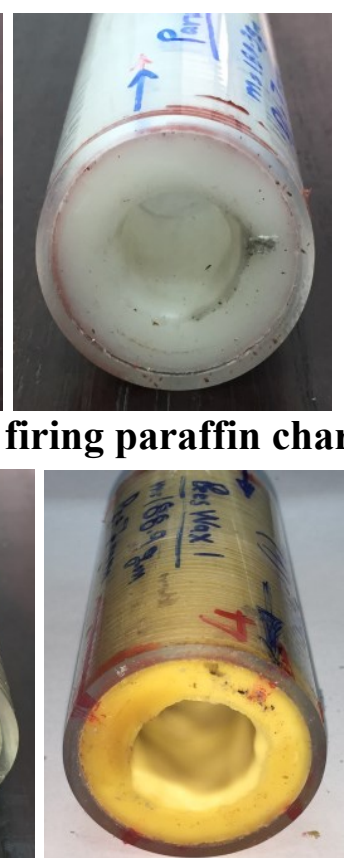

Fig. (5) A sample function test

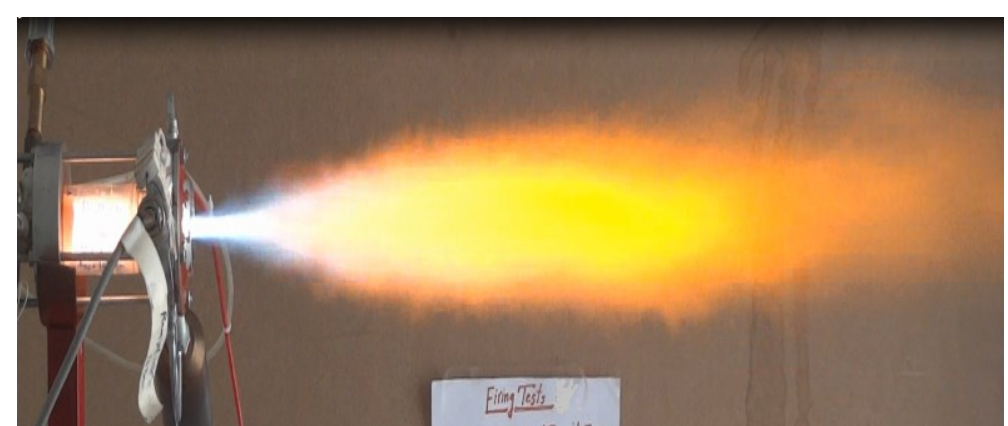

d) Paraffin + GO2 firing

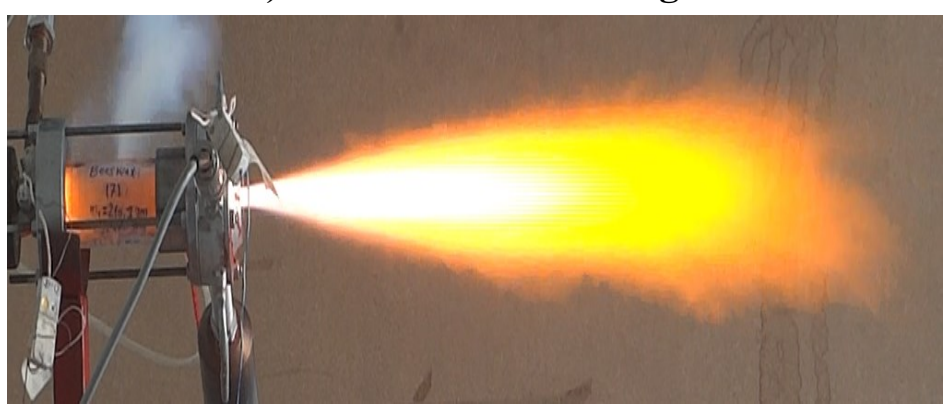

e) Beeswax + GO2 firing 
Military Technical College

Kobry El-Kobbah,

Cairo, Egypt

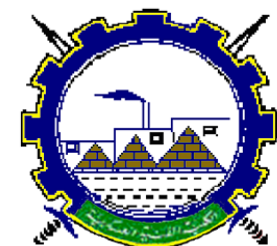

I.C.E.E.2016 $8^{\text {th }}$ International Conference

on

Chemical \& Environmental

Engineering

19 - 21 April 2016

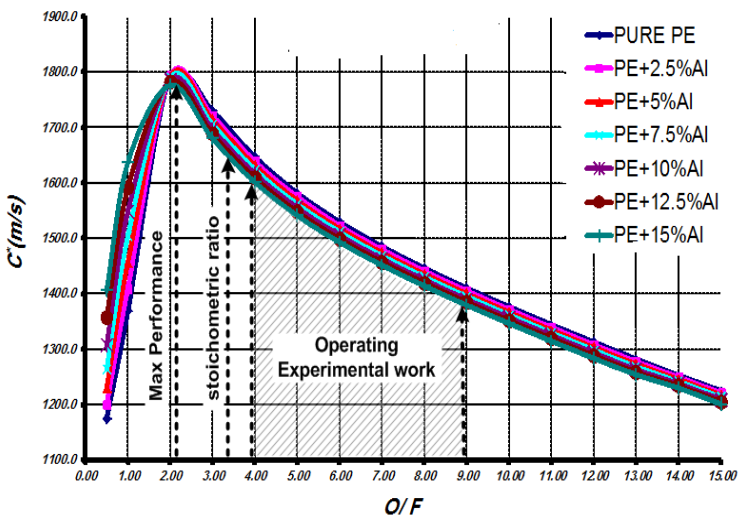

(a) Characteristic velocity versus $\mathrm{O} / \mathrm{F}$

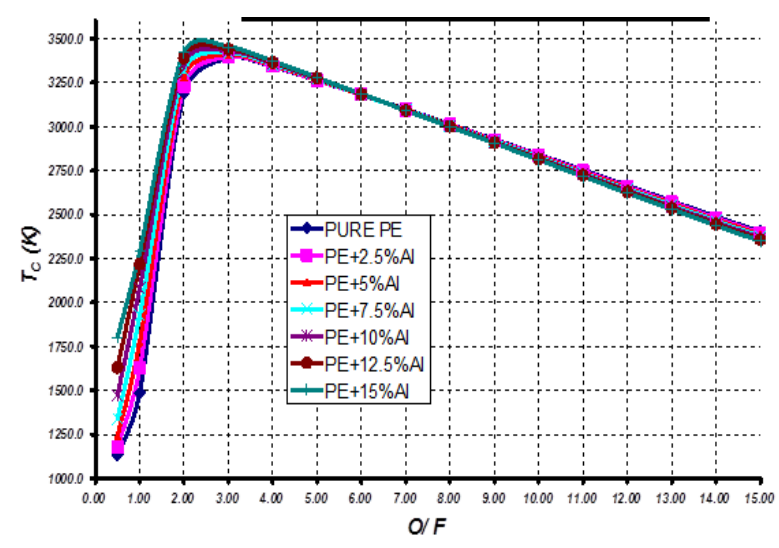

(c) Chamber temperature versus $\mathrm{O} / \mathrm{F}$

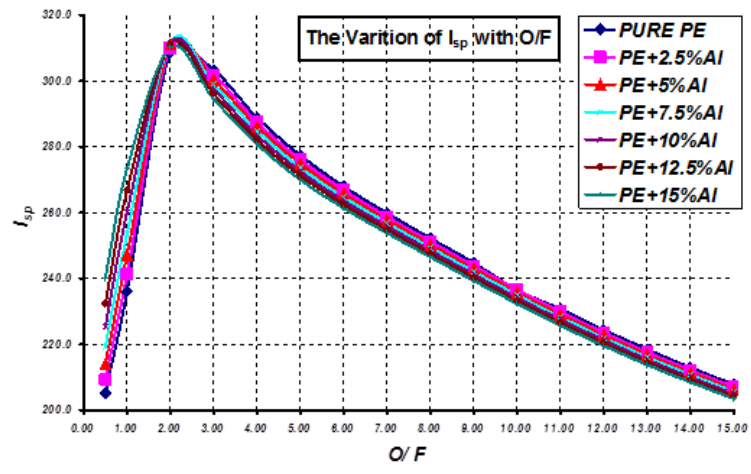

(b) Specific impulse versus $\mathrm{O} / \mathrm{F}$

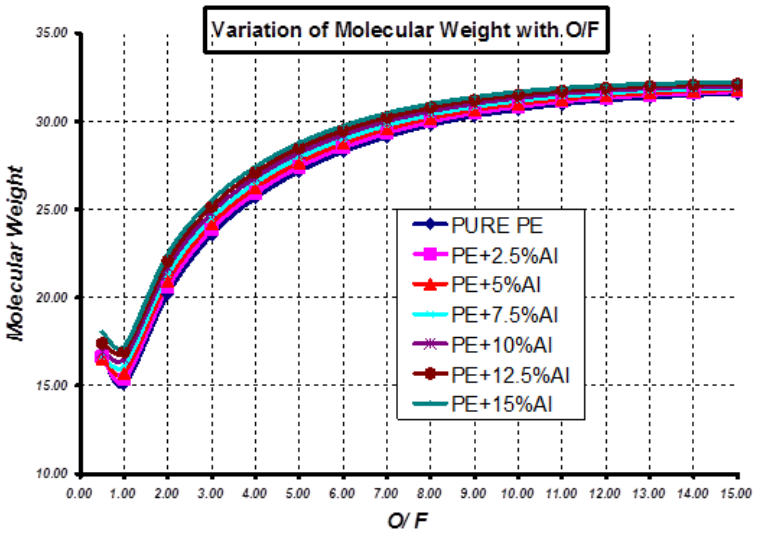

(d) Molecular weight versus $\mathrm{O} / \mathrm{F}$

Fig. (6 ) $\mathrm{PE}+\mathrm{Al}+\mathrm{O}_{2}$ Propellant performance parameter versus $\mathrm{O} / \mathrm{F}$ 